\title{
Effect of Intercropping Onion with Sugar Beet on Productivity of Both Crops and Root-Knot Nematodes Control under Different Onion Plant Densities and Slow-Release N Fertilizer Rates
}

\author{
Ahmed M. Abd Allah ${ }^{1}$; Amira A. El-Mehy ${ }^{* 1}$ and Sahar H. Abdel-Baset ${ }^{* 2}$ \\ ${ }^{1}$ Crop Intensification Research Department, Field Crops Res. Inst., A.R. C., Giza, Egypt \\ ${ }^{2}$ Department of Nematology, Plant Pathology Res. Inst., A.R.C., Giza, Egypt
}

Received: $17 / 11 / 2020$

\begin{abstract}
A field experiment was conducted over two growing seasons 2018/19 and 2019/20, at Ismailia Agric. Exper. and Res. Station, A.R.C., to determine the effect of onion plant densities (2, 3 and 4 rows of onion intercropped with sugar beet) and four nitrogen fertilizer rates $(60,80$ and $100 \mathrm{~kg} \mathrm{~N} / \mathrm{fad})$ as blending fertilizer of urea formaldehyde (UF as slow-release $\mathrm{N}$ ) and traditional urea (TU) compared to control treatment (100 kg N/fad as TU) on productivity, control of root-knot nematodes Meloidogyne spp., land and $\mathrm{N}$ use efficiency as well as net return. Results showed that, intercropping two rows of onion with sugar beet significantly increased root, top and sugar yields/fad of sugar beet, TSS\% and bulb characters as well as NUE compared to 3 and 4 rows of onion. Meanwhile, increasing onion plant density up to four rows significantly increased plant height and onion yield/fad. Slow-release $\mathrm{N}$ fertilizer had a significant effect on sugar beet and onion traits. The blending fertilizer of UF at $100 \mathrm{~kg} \mathrm{~N} / \mathrm{fad}$ had the highest sugar beet and onion productivity, while $\mathrm{N}$ rate at $80 \mathrm{~kg} /$ fad had the highest sugar yield/fad and NUE. Intercropping two rows of onion with application UF+TU at 100 or $80 \mathrm{~kg} \mathrm{~N} / \mathrm{fad}$ had the highest values of sugar beet and onion traits, without significant differences in most cases. The applying treatments were studied against root-knot nematodes under field conditions. Generally, the nematode parameters were negatively correlated with intercropping onion with sugar beet compared to check treatment (solid sugar beet). The most effective treatment in reducing the number of galls, eggmasses per root system, root gall index (RGI), egg -masses index (EI) as well as a number of second-stage juveniles $\left(\mathrm{j}_{2}\right.$ ) in soil was 4 rows with $80 \mathrm{~kg}$ nitrogen in two successive seasons. Intercropping two rows of onion with sugar beet and application blending $\mathrm{N}$ fertilizer of UF at $80 \mathrm{~kg} \mathrm{~N} / \mathrm{fad}$ had the highest LER value 1.31 and 1.34 and maximizing net return/fad compared to solid sugar beet. Therefore, growing two rows of onion with sugar beet that received $80 \mathrm{~kg}$ $\mathrm{N} /$ fad as a mixture of UF and TU could be controlled root-knot nematodes, Meloidogyne spp. and increased sugar beet productivity, maximizing land use and grower profitability as well as reduced $\mathrm{N}$ fertilizer usage.
\end{abstract}

Keywords: Intercropping, urea formaldehyde (UF), traditional urea (TU), nitrogen use efficiency (NUE), root-knot nematodes, Meloidogyne spp., economic evaluation

\section{INTRODUCTION}

To meet the increasing demand of food due to overpopulation in Egypt, intercropping is needful to increase the yield per unit area. Where suitable land area for agricultural production fixed or is diminishing. Intercropping is a useful technique for increasing productivity per unit area, as one crop shares its life cycle or part of it with another crop (Eskandari, 2012), increased net income (Abdel Motagally and Metwally, 2014) and reduce weeds, pests, and diseases (Agu, 2008).

Sugar beet as (C3 crop) has a slow growth rate, especially at early growth stages, which encourage to intercropping some winter crops with sugar beet to increase food production per unit area and farmers benefit. Onion is very much suited to intercropping with sugar beet. This crop is shallow-rooted bulbs and having a low canopy, so they do not compete with space and deep-rooted long duration crop. These differences in foliage display and rooting patterns create the space dimension of intercropping (Dunin et al., 1999).

The effect of intercropping on the root yield of sugar beet and quality mainly depends on the cropping pattern. Besheit et al. (2002) showed that the highest sugar beet quality and productivity were obtained from

*Corresponding author e-mail: drsaharhassan14@gmail.com e-mail: amiraelmehy123@yahoo.com beet intercropped with two onion rows on ridge (100 $\mathrm{cm}$ ) width, while intercropping onion on the other side of sugar beet ridge $(50 \mathrm{~cm})$ width was higher and negative affected sugar beet quality and quantity intercropped with onion. El-Shamy et al. (2015) noticed that the highest values of root and gross sugar yields were produced by the pure stand of sugar beet, followed by one rows of onion intercropped with sugar beet. Meanwhile, the lowest mean values were recorded under three rows of onion intercropped with sugar beet in the two growing seasons. However, insignificant reduction in sugar beet yield as well as the highest values of land equivalent ratio (LER) and gross return when intercropped sugar beet with onion reported by Farghaly et al. (2003), Abdel Motagally and Metwally (2014), Masri and Safina (2015).

Slow-release nitrogen fertilizer has been suggested as a potential $\mathrm{N}$ fertilizer for sandy soil that controls $\mathrm{N}$ leaching and increases $\mathrm{N}$ use efficiency. The application of slow-release $\mathrm{N}$ fertilizer gave maximum yield production (Bahr et al., 2006; Ahmed et al., 2007). Sims (2010) reported that slower release may be beneficial to sugar beet root growth and quality. Sub-optimal $\mathrm{N}$ rates reduce root yield and sucrose per acre while over-application decreases sucrose concentration, increases impurities, and increases environmental concerns (Hergert, 2010). 
Recently, Norton (2011) notice that all products slowrelease $\mathrm{N}$ yielded significantly more root mass than the control plots (urea). Full $\mathrm{N}$ rate of slow-release $\mathrm{N}$ products resulted in significantly lower sugar content than the control. Meanwhile, El-Shazly et al. (2014) reported that application nitrogen in different sources, significantly affect the root and sugar yields, TSS\%, sucrose $\%$ and purity $\%$, whereas the superiority was for urea formaldehyde comparison with ammonium sulfate and ammonium nitrate.

Root-knot nematode species, Meloidogyne spp., have been reported as major nematode pests of sugar beet in Egypt (Gohar and Maareg, 2005; Gohar et al., 2012). Plant parasitic nematodes cause serious damage and yield losses in a wide range of crops throughout the world estimated to cause $>\$ 80$ billion losses annually (Nicol et al., 2011). The average loss in sugar beet yield in Egypt due to $M$. incognita in different areas was estimated to be $>50 \%$ in sugar yield and $>$ $68 \%$ of roots yield for susceptible varieties (Gohar and Maareg, 2005).

Due to their adverse effects on human health and the environment, chemical nematicides are being banned worldwide. Therefore, an urgent need for alternative and efficient control measures as well as improved agricultural practices to minimize crop losses. Various plants are effective in controlling nematodes on agricultural crops when grown in rotation, inter-planted with susceptible crops (Halbrendt, 1996). A variety of plant metabolites in roots and exuded from roots to the rhizosphere influence nematode behaviour, development, reproduction and even survival (Dandurand and Knudsen, 2016; Li et al., 2018). Some metabolites thus facilitate plant-parasitic nematode infection and damage, whereas others directly or indirectly reduce damage. Inclusion of plants with high contents of nematicidal or nematode inhibitory compounds in cropping systems as a sanitation strategy has thus received considerable research attention and is also applied in practice. Further, the application of purified nematicidal plant-derived compounds may be an efficient nematode management strategy (Zanón et al., 2014). Allium spp. (e.g. onion) contains sulfur aminoacid precursors in their cytoplasm, which upon cellular degradation are broken down by the enzyme alliinase to a new volatile organic compound, dimethyl disulfide (DMDS) (Haroutunian, 2013).

The objective of this study is to find the best effective onion plant density intercropped with sugar beet and slow-release $\mathrm{N}$ fertilizer rate that control rootknot nematodes, Meloidogyne spp. of sugar beet, increased productivity, reduced $\mathrm{N}$ fertilizer usage as well as increased land equivalent ratio and farmer's profitability.

\section{MATERIALS AND METHODS}

\section{Experimental site:}

A field experiment was implemented in Ismailia Agricultural Experiments and Research Station, A.R.C., Ismailia governorate (Lat. $30^{\circ} 35^{\prime} 30^{\prime \prime} \mathrm{N}$,
Long. 32 14 ' 50" E, $10 \mathrm{~m}$ a.s.1.), Egypt during two successive seasons 2018/19 and 2019/20. The previous studies determined that field naturally infested with root-knot nematodes Meloidogyne spp. The experimental soil texture was sandy as shown in Table (1), according to the analytical methods chosen at random from each plot as described by Black et al. (1982).

Table (1): Some physical and chemical properties of the experimental soil

\begin{tabular}{|c|c|c|c|}
\hline $\begin{array}{l}\text { Soil } \\
\text { characteristics }\end{array}$ & Values & $\begin{array}{l}\text { Soil } \\
\text { characteristics }\end{array}$ & Values \\
\hline $\begin{array}{l}\text { Particle size } \\
\text { distribution \% }\end{array}$ & & $\begin{array}{l}\text { Soluble cations an } \\
\text { anions }\left(\mathrm{meq}^{-1}\right)\end{array}$ & \\
\hline Coarse sand & 50.4 & $\mathrm{Ca}++$ & 1.50 \\
\hline Fine sand & 40.4 & $\mathbf{M g + +}$ & 0.95 \\
\hline Silt & 6.0 & $\mathbf{N a}+$ & 0.89 \\
\hline Clay & 3.2 & $\mathbf{K}+$ & 0.45 \\
\hline \multirow[t]{2}{*}{ Texture class } & Sandy & $\mathrm{HCO3}^{--}$ & 1.02 \\
\hline & & $\mathrm{Cl}^{-}$ & 1.42 \\
\hline $\begin{array}{l}\text { Chemical } \\
\text { properties }\end{array}$ & & $\mathrm{SO}^{--}$ & 1.35 \\
\hline $\begin{array}{l}\text { pH (suspension } \\
1: 2.5)\end{array}$ & 8.03 & $\begin{array}{l}\text { Available nutrient } \\
\left(\mathrm{mg} \mathrm{Kg}^{-1}\right)\end{array}$ & \\
\hline $\begin{array}{l}\mathrm{EC} \mathrm{dSm}^{-1} \\
\text { (saturated soil } \\
\text { paste extract) }\end{array}$ & 1.06 & $\mathbf{N}$ & 45 \\
\hline \multirow{2}{*}{$\begin{array}{l}\text { Organic } \\
\text { matter \% }\end{array}$} & 0.38 & $\mathbf{P}$ & 11 \\
\hline & & $\mathbf{K}$ & 50 \\
\hline
\end{tabular}

\section{Experimental design and treatments:}

The experimental layout was arranged in a splitplot design in RCBD arrangement with three replications. The plot size was $14.4 \mathrm{~m}^{2}$, having four beds $3.0 \mathrm{~m}$ length and $1.2 \mathrm{~m}$ width. Plant density of onion randomly assigned to the main plots and different $\mathrm{N}$ fertilizer rates were allocated in subplots.

The experiment included 12 treatments which were the combination between three onion plant densities (2, 3 and 4 rows of onion intercropped with sugar beet) and four $\mathrm{N}$ fertilizer rates for each crop were 60,80 and $100 \mathrm{~kg} \mathrm{~N} /$ fad as blending fertilizer of urea formaldehyde (UF) as slow-release $\mathrm{N}$ (Enciabin $40 \% \mathrm{~N}$ ) and traditional urea 46.5\% N (TU) 50:50 weight, compared to $100 \mathrm{~kg} \mathrm{~N} / \mathrm{fad}$ as traditional urea (control treatment). For the intercropping onion, different $\mathrm{N}$ rates were added according to plant density of onion.

\section{The experiment treatments were as follows:}

Under all intercropping treatments, sugar beet seeds were sown in both sides of the bed $(120 \mathrm{~cm}$ width) by growing one plants/hill distanced at $20 \mathrm{~cm}$, while onion took place on the back of sugar beet bed in 2,3 and 4 rows at $10 \times 15 \mathrm{~cm}$ that is received $\mathrm{N}$ fertilizer rates as follows: 
1. Intercropping 2 rows of onion with sugar beet that received $60 \mathrm{~kg} \mathrm{~N} / \mathrm{fad}$ of sugar beet and $19.9 \mathrm{~kg}$ $\mathrm{N} /$ fad of onion, as blending fertilizer.

2. Intercropping 2 rows of onion with sugar beet that received $80 \mathrm{~kg} \mathrm{~N} /$ fad of sugar beet and $26.6 \mathrm{~kg}$ $\mathrm{N} /$ fad of onion, as blending fertilizer.

3. Intercropping 2 rows of onion with sugar beet that received $100 \mathrm{~kg} \mathrm{~N} /$ fad of sugar beet and $33.3 \mathrm{~kg}$ $\mathrm{N} /$ fad of onion, as blending fertilizer.

4. Intercropping 2 rows of onion with sugar beet that received $100 \mathrm{~kg} \mathrm{~N} / \mathrm{fad}$ of sugar beet and $33.3 \mathrm{~kg}$ $\mathrm{N} /$ fad of onion as traditional urea (control).

5. Intercropping 3 rows of onion with sugar beet that received $60 \mathrm{~kg} \mathrm{~N} /$ fad of sugar beet and $30 \mathrm{~kg} \mathrm{~N} / \mathrm{fad}$ of onion, as blending fertilizer.

6. Intercropping 3 rows of onion with sugar beet that received $80 \mathrm{~kg} \mathrm{~N} / \mathrm{fad}$ of sugar beet and $40 \mathrm{~kg} \mathrm{~N} / \mathrm{fad}$ of onion, as blending fertilizer.

7. Intercropping 3 rows of onion with sugar beet that received $100 \mathrm{~kg} \mathrm{~N} / \mathrm{fad}$ of sugar beet and $50 \mathrm{~kg}$ $\mathrm{N} /$ fad of onion, as blending fertilizer.

8. Intercropping 3 rows of onion with sugar beet that received $100 \mathrm{~kg} \mathrm{~N} / \mathrm{fad}$ of sugar beet and $50 \mathrm{~kg}$ $\mathrm{N} /$ fad of onion as traditional urea (control).

9. Intercropping 4 rows of onion with sugar beet that received $60 \mathrm{~kg} \mathrm{~N} / \mathrm{fad}$ of sugar beet and $40 \mathrm{~kg} \mathrm{~N} / \mathrm{fad}$ of onion, as blending fertilizer.

10. Intercropping 4 rows of onion with sugar beet that received $80 \mathrm{~kg} \mathrm{~N} / \mathrm{fad}$ of sugar beet and $53.4 \mathrm{~kg}$ $\mathrm{N} /$ fad of onion, as blending fertilizer.

11. Intercropping 4 rows of onion with sugar beet that received $100 \mathrm{~kg} \mathrm{~N} /$ fad of sugar beet and $66.7 \mathrm{~kg}$ $\mathrm{N} /$ fad of onion, as blending fertilizer.

12. Intercropping 4 rows of onion with sugar beet that received $100 \mathrm{~kg} \mathrm{~N} /$ fad of sugar beet and $66.7 \mathrm{~kg}$ $\mathrm{N} /$ fad of onion, as urea without form traditional urea (control).

In addition to solid culture, sugar beet seeds were growing in both sides of bed $120 \mathrm{~cm}$ width by growing one plant hill ${ }^{-1}$ at $20 \mathrm{~cm}$ distance, while onion transplanting in 6 rows on bed $120 \mathrm{~cm}$ width at $10 \times 15$ $\mathrm{cm}$, that received $100 \mathrm{~kg} \mathrm{~N} / \mathrm{ha}$ as urea. This pattern was used only for competitive relationships.

\section{Field practices:}

Maize was the preceding summer crop in both seasons. Sprinkler irrigation was the irrigation system in this study. Sugar beet (cv. Sarah Hs0061) and onion (cv. Giza 20) were used. Planting date of sugar beet was November $1^{\text {st }}$ and October $25^{\text {th }}$ in 2018/2019 and 2019/2020 seasons, respectively, meanwhile onion transplanting on December $7^{\text {th }}$ and $1^{\text {st }}$ in 2018/2019 and 2019/2020 seasons, respectively. Sugar beet and onion plants were harvested on May $8^{\text {th }}$ and $5^{\text {th }}$ in first and second season, respectively. The recommended dose of mineral $\mathrm{N}$ fertilizer of sugar beet and onion was added at a rate of $100 \mathrm{~kg} \mathrm{~N}^{-1}$ as urea "46.5\% N" under sole cultures and control treatment in intercropping culture. Urea formaldehyde as slow-release $\mathrm{N}$ doses were applied at sowing, whereas, urea $(46.5 \%)$ divided into 6 equal doses for sugar beet, and 5 equal doses for onion. Slow-release N fertilizer (Enciabien 40\% N) was obtained by the General Organization for Agricultural Equalization Fund, ARC, Giza, Egypt.

\section{The studied traits}

Growth, yield and quality characters of sugar beet:

At harvest, the following traits were measured on five plants from each sub-plot: Root length $(\mathrm{cm})$, root diameter $(\mathrm{cm})$, root and top weight/plant $(\mathrm{g})$. Root and top yields fad ${ }^{-1}$ were recorded based on the subplot area by harvesting all plants and then converted to tonfad ${ }^{-1}$. Quality traits were TSS (total soluble solids, $\%$ ), Sucrose $\%$ and purity $\%$. Sugar yield ton $\mathrm{fad}^{-1}=$ root yield/fad x sucrose $\%$.

\section{Growth and yield characters of onion:}

At harvest, five plants of onion were randomly taken to estimated: Plant height $(\mathrm{cm})$, number of leaves/plant, bulb diameter $(\mathrm{cm})$ and bulb weight $(\mathrm{g})$. Onion yield (tonfad ${ }^{-1}$ ) determined on the basis of subplot and then converted to ton $\mathrm{fad}^{-1}$

\section{Nitrogen use efficiency (NUE) of both crops:}

The $\mathrm{N}$ use efficiency of mineral $\mathrm{N}$ fertilization of sugar beet was calculated by this equation, according to (Craswell and Godwin, 1984):

\section{NUE $=($ Yield F - Yield C) / Fertilizer Napplied kg/kg}

Where F: fertilized sugar beet or onion at 80 and 100 $\mathrm{kg}$ with or without urea formaldehyde and $\mathrm{C}$ : unfertilized control (the application of $60 \mathrm{~kg}$ ).

\section{Nematode parameters assessment:}

The experiments were conducted at the field naturally infested with root-knot nematodes Meloidogyne spp., during two successive seasons. At harvest, the roots of three plants of each plot were gently washed in tap water, these roots were stained by dipping for $20 \mathrm{~min}$ in a solution of 0.015 percent Phloxine B (Daykin and Hussey, 1985) for counting the number of egg masses per plant. The number of root galls was counted, root galls (RGI) and egg masses (EI) indices were measured at $0-5$ scale: $0=$ no galls/egg masses; $1=1$ or $2 ; 3=11-30 ; 4=31-100$; and $5=>100$ galls or egg masses per root system (Taylor and Sasser, 1978). Two hundred and fifty $g$ of soil from each plot was used to extract nematode, using sieving and Baermann pan technique (Barker, 1985). The extracted juveniles were counted by using $1 \mathrm{ml}$ counting slide under the stereoscopic microscope and the average number of second-stage juveniles $\left(\mathrm{j}_{2}\right) / 250$ $\mathrm{g}$ soil was calculated for each intercropping treatment. A comparison treatment with the nematicide Vydate ${ }^{\circledR}$ (oxamyl) $24 \% \mathrm{~L}$, was added at the rate of $4 \mathrm{~L} /$ fad as recommended.

\section{Competitive relationships: \\ Land equivalent ratio (LER)}

LER defines as the ratio of area needed under sole cropping to one of intercropping at the same management level to produce an equivalent yield (Mead and Willey, 1980). It is calculated as follows: $L E R=\frac{Y_{a b}}{Y_{a a}}+\frac{Y_{b a}}{Y_{b b}}$ 
Where: $\mathrm{Y}_{\mathrm{aa}}$ and $\mathrm{Y}_{\mathrm{ab}}=$ Pure and intercropping stand yield of crop a (sugar beet)

$\mathrm{Y}_{\mathrm{bb}}$ and $\mathrm{Y}_{\mathrm{ba}}=$ Pure and intercropping stand yield of crop b (onion), respectively.

Relative crowding coefficient (RCC) K: It was estimated by multiplying the coefficient for the sugar crop $\left(\mathrm{K}_{\mathrm{ab}}\right)$ by the coefficient of the onion crop $\left(\mathrm{K}_{\mathrm{ba}}\right)$ by Dewit (1960) as follows: $K=K_{a b} \times K_{b a}$

$$
\begin{aligned}
K_{a b} & =\frac{Y_{a b} \times Z_{b a}}{\left(Y_{a a}-Y_{a b}\right) \times Z_{a b}} \\
K_{b a} & =\frac{Y_{b a} \times Z_{a b}}{\left(Y_{b b}-Y_{b a}\right) \times Z_{b a}}
\end{aligned}
$$

Where: $Z_{\mathrm{ab}}=$ the area ratio of the crop (sugar beet) when intercropping

$\mathrm{Z}_{\mathrm{ba}}=$ the area ratio of the crop (onion) when intercropping

\section{Economic evaluation:}

Farmer's benefit was calculated by determining the total costs and net return of intercropping culture as compared to recommended solid culture of sugar beet.

- Gross returnfad ${ }^{-1}=$ Price of sugar beet yield + price of onion yield (L.E.).

- Net returnfad ${ }^{-1}=$ Total return - (fixed costs of sugar beet + variable costs of onion according to the intercropping pattern).

The average of sugar beet and onion price presented by Bulletin of Statistical Cost Production and Net Return (Bulletin, 2018). The local prices were L.E. 520 of one ton of sugar beet root and L.E. 2000 of one ton of onion.

\section{The statistical analysis:}

Analysis of variance of the obtained results of each season was performed. The measured variables were analyzed by ANOVA using MSTATC statistical pack-age (Freed, 1991). Mean comparisons were performed using the least significant differences (L.S.D) test with a significance level of 5\% (Gomez and Gomez, 1984).

\section{RESULTS AND DISCUSSION}

\section{Sugar beet yield and its attributes:}

\section{Effect of onion plant densities:}

Root length, root diameter, root weight/plant and root, top and sugar yields/fad were significantly affected by onion plant density in two growing seasons, whereas top weight/plant was not significantly affected by intercropping onion with sugar beet in the first season as shown in Table (2).

Increasing onion plant density from 2 to 4 rows significantly decreased root length by 20.77 and $20.28 \%$, root diameter 10.55 and $9.93 \%$, root weight/plant 5.39 and $10.93 \%$, top weight/plant 7.02 and $17.65 \%$, root yield/fad 9.78 and $13.22 \%$, top yield/fad 9.72 and $17.17 \%$ and sugar yield/fad by 8.50 and 12.56 in first and second seasons, respectively. These data may be due to intercropping sugar beet with the highest onion plant density (four rows of onion) affected negatively the response of sugar beet plant to intercept more solar radiation compared to those grown with the other onion plant densities under sandy soil conditions. It is important to mention that number of onion rows per unit area could be related to competition degree between sugar beet and onion on nutrients, carbon dioxide solar radiation and water, therefore, the highest competition evident with the highest density of onion plants. Nevertheless, intercropping onion with sugar beet slightly decreased values of the previous traits comparison with solid sugar beet. El-Shamy et al. (2015) noticed that the highest values of root and gross sugar yields were produced by the pure stand of sugar beet. Meanwhile, the lowest mean values were recorded under the highest onion plant density, 3 rows of onion intercropped with sugar beet in the two growing seasons. These results are in a great agreement with those obtained by Besheit et al. (2002), Ibrahim et al. (2005), Abdel Motagally and Metwally (2014), Masri and Safina (2015).

Also, data in Table (2) indicated that plant density of onion intercropped with sugar beet had a significant effect on total soluble sugars in both seasons and sucrose $\%$ in the second season, while purity $\%$ was not significantly affected in both seasons. The highest $\mathrm{TSS} \%$ and sucrose $\%$ were obtained by intercropping two and three rows of onion with sugar beet, respectively, while the lowest values were achieved with the solid culture of sugar beet in both seasons. Interpretation of this criterion could be attributed to the weight and size of root rather than the effect of the intercropping pattern. Both traits seemed to be exclusively associated with root weight and governed by the dilution theory. The higher root weight was, the less the total soluble sugars, sucrose and purity percentage were obtained. Abdel Motagally and Metwally (2014) found that purity \% were not significant affected by intercropping sugar beet with onion in both seasons, while sucrose \% was not significantly affected in the first season, while it was highly significant in the second season. Similar results were obtained by Masri and Safina (2015).

Concerning nitrogen use efficiency of fresh root yield/fad, data in Table (2) showed that increasing plant density of onion intercropped with sugar beet from two to three and four rows significantly decreased NUE in both seasons. These results may be attributed to low onion plant density decreased intra and interspecific competition among two species, consequently increased plant efficiency to use $\mathrm{N}$ fertilizer and convert it to biomass. These results hold true in two growing seasons and were harmony with those obtained by Abdel-Wahab and El Manzlawy (2016) intercropping faba bean with four rows of wheat increased NUE by $15.27 \%$ compared to those grown with six rows of wheat. 
Table (2): Effect of onion plant densities on sugar beet characters in 2018/2019 and 2019/2020 seasons

\begin{tabular}{|c|c|c|c|c|c|c|c|c|}
\hline \multirow{2}{*}{ Treatment } & \multicolumn{2}{|c|}{ Root length (cm) } & \multicolumn{2}{|c|}{ Root diameter $(\mathrm{cm})$} & \multicolumn{2}{|c|}{ Root weight(g) } & \multicolumn{2}{|c|}{ Top weight(g) } \\
\hline & 2018/19 & $2019 / 20$ & 2018/19 & $2019 / 20$ & 2018/19 & $2019 / 20$ & $2018 / 19$ & $2019 / 20$ \\
\hline \multicolumn{9}{|c|}{ Onion plant densities } \\
\hline 2 rows & 22.15 & 23.72 & 9.95 & 11.08 & 732.40 & 754.58 & 363.00 & 344.58 \\
\hline 3 rows & 20.00 & 21.60 & 9.17 & 10.33 & 705.26 & 731.67 & 357.00 & 313.34 \\
\hline 4 rows & 17.55 & 18.91 & 8.90 & 9.98 & 692.94 & 672.08 & 337.50 & 283.75 \\
\hline F test & $*$ & $* *$ & $*$ & $* *$ & $*$ & $* *$ & N.S & $* *$ \\
\hline LSD A at 0.05 & 1.29 & 1.21 & 0.30 & 0.46 & 10.28 & 11.01 & N.S & 3.78 \\
\hline Solid culture & 24.66 & 25.96 & 10.32 & 11.59 & 823.22 & 838.00 & 370.67 & 406.07 \\
\hline \multirow[b]{2}{*}{ Treatment } & \multicolumn{3}{|c|}{ Root yield (T/fed) } & \multicolumn{2}{|c|}{ Top yield (t/fed) } & \multicolumn{3}{|c|}{ Sugar yield (t/fed) } \\
\hline & $2018 / 19$ & \multicolumn{2}{|c|}{$2019 / 20$} & $2018 / 19$ & $2019 / 20$ & \multicolumn{2}{|c|}{$2018 / 19$} & $019 / 20$ \\
\hline \multicolumn{9}{|l|}{ Onion plant densities } \\
\hline 2 rows & \multicolumn{3}{|l|}{23.289} & 10.351 & 10.727 & \multicolumn{2}{|c|}{4.142} & 4.220 \\
\hline 3 rows & 21.900 & \multicolumn{2}{|c|}{22.146} & 10.068 & 9.818 & \multicolumn{2}{|c|}{3.951} & 4.016 \\
\hline 4 rows & 21.012 & \multicolumn{2}{|c|}{20.470} & 9.345 & 8.885 & \multicolumn{2}{|c|}{3.790} & 3.690 \\
\hline F test & $* *$ & \multicolumn{2}{|c|}{$* *$} & $*$ & $* *$ & $* *$ & & $* *$ \\
\hline LSD A at 0.05 & 0.474 & & & 899 & 0.459 & 0.0 & & 0.059 \\
\hline Solid culture & 24.905 & & & 854 & 12.793 & 4.2 & & 4.289 \\
\hline $\begin{array}{cc} & \text { Trait } \\
\text { Treatment } & \end{array}$ & $\begin{array}{r}\text { TS } \\
\text { \% } \\
\end{array}$ & & & & & & $\begin{array}{r}\text { NUE o } \\
k\end{array}$ & $\begin{array}{l}\text { oot yield } \\
\text { /kg }\end{array}$ \\
\hline oreatment & $2018 / 19$ & $2019 / 20$ & $2018 / 19$ & $2019 / 20$ & $2018 / 19$ & $2019 / 20$ & $2018 / 19$ & $2019 / 20$ \\
\hline Onion plant densiti & & & & & & & & \\
\hline 2 rows & 21.78 & 21.98 & 17.80 & 17.90 & 81.73 & 81.43 & 77.21 & 70.61 \\
\hline 3 rows & 21.54 & 21.84 & 18.05 & 18.14 & 83.80 & 83.07 & 62.12 & 55.43 \\
\hline 4 rows & 21.43 & 21.68 & 18.05 & 18.03 & 84.21 & 83.17 & 54.94 & 39.48 \\
\hline F test & $* *$ & $* *$ & N.S & $* *$ & N.S & N.S & $*$ & $* *$ \\
\hline LSD A at 0.05 & 0.09 & 0.06 & N.S & 0.05 & N.S & N.S & 4.16 & 3.03 \\
\hline Solid culture & 20.89 & 21.05 & 16.92 & 17.05 & 80.95 & 81.00 & - & - \\
\hline
\end{tabular}

\section{Effect of slow-release $\mathbf{N}$ fertilizer rates:}

Application different rates of blending $\mathrm{N}$ fertilizer significantly affect the root length, root diameter, root weight/plant, top weight/plant, root, top and sugar yields/fad as shown in Table (3). The superiority was for $100 \mathrm{~kg} \mathrm{~N} /$ fad mixture of urea formaldehyde and traditional urea (50:50 wt.), followed by $80 \mathrm{~kg} \mathrm{~N} / \mathrm{fad}$, while the lowest values of the previous traits were produced when sugar beet fertilizing by blending $\mathrm{N}$ fertilizer at $60 \mathrm{~kg} \mathrm{~N} / \mathrm{fad}$. However, the differences between 100 and $80 \mathrm{~kg} \mathrm{~N} /$ fad were insignificant in most cases, whereas control (100 kg N/fad without urea formaldehyde) ranked the third position. Increasing mixture $\mathrm{N}$ rates up to $100 \mathrm{~kg} / \mathrm{fad}$ achieved the highest root and top yields/fad, meanwhile, the highest sugar yield per fad was produced by increasing $\mathrm{N}$ rates up to $80 \mathrm{~kg} \mathrm{~N} / \mathrm{fad}$. The superiority of mixture UF and TU fertilizer at 80 or $100 \mathrm{~kg}$ than control may be due to the regulation of nutrient release and enhancement the nitrogen use efficiency by plants and subsequently reducing $\mathrm{N}$ leaching losses and provide a constant supply of nutrients to the roots. These results confirmed by Bahr et al. (2006), Ahmed et al. (2007) and Norton (2011). Similarly, El-Shazly et al. (2014) reported that application nitrogen in different sources significantly affect the root and sugar yields, where urea formaldehyde produced the highest values in comparison with ammonium sulfate and ammonium nitrate.

Significant differences in all quality traits of sugar beet were noticed due to slow-release nitrogen fertilizer rates in both seasons (Table 3). The highest values of TSS \% were obtained by control $(100 \mathrm{~kg}$ urea/fad) in two growing seasons. However, the highest means of sucrose $\%$ and purity $\%$ resulted from the application of $60 \mathrm{~kg} \mathrm{~N} /$ fadas mixture in both seasons. Contrary, increasing $\mathrm{N}$ rate up to $100 \mathrm{~kg} / \mathrm{fad}$ as mixture significantly decreased sucrose $\%$ and purity $\%$. The reduction in root quality due to increasing nitrogen fertilizer rates may be attributed to the role of nitrogen in increasing non sucrose substances such as alpha-amino acid and proteins, and hence decreasing sucrose content in roots. Moreover, the fact that increasing nitrogen levels result in increased water retention by the tap root and in turn decrease sucrose percentage of root fresh weight (Draycott, 1993). Similarly, Hergert (2010) who found that sub-optimal $\mathrm{N}$ rates reduce root yield and sucrose per acre while over-application decreases sucrose concentration, increases impurities, and increases environmental concerns. 
Table (3): Effect of slow-release N fertilizer rates on sugar beet characters in 2018/2019 and 2019/2020 seasons

\begin{tabular}{|c|c|c|c|c|c|c|c|c|}
\hline \multirow[b]{2}{*}{ Treatment } & \multicolumn{2}{|c|}{ Root length (cm) } & \multicolumn{2}{|c|}{ Root diam.(cm) } & \multicolumn{2}{|c|}{ Root weight (g) } & \multicolumn{2}{|c|}{ Top weight (g) } \\
\hline & $2018 / 19$ & $2019 / 20$ & $2018 / 19$ & $2019 / 20$ & $2018 / 19$ & $2019 / 20$ & $2018 / 19$ & $2019 / 20$ \\
\hline \multicolumn{9}{|c|}{$\mathrm{N}$ fertilizer rates $\mathrm{kg} / \mathrm{fed}$} \\
\hline 60 & 18.80 & 18.81 & 8.33 & 9.37 & 654.73 & 687.22 & 311.33 & 299.44 \\
\hline 80 & 20.55 & 21.82 & 9.83 & 10.89 & 734.21 & 737.78 & 359.67 & 313.89 \\
\hline 100 & 20.59 & 22.85 & 10.00 & 11.04 & 740.60 & 750.00 & 387.00 & 333.89 \\
\hline Control & 19.66 & 22.15 & 9.20 & 10.53 & 712.53 & 702.78 & 352.00 & 308.33 \\
\hline F test & $* *$ & $* *$ & $*$ & $* *$ & $*$ & $* *$ & $* *$ & $* *$ \\
\hline LSD B at 0.05 & 1.31 & 1.23 & 0.49 & 0.32 & 10.03 & 13.64 & 9.51 & 5.37 \\
\hline \multirow[b]{2}{*}{ Treatment } & \multicolumn{2}{|c|}{ Root yield (t/fed) } & \multicolumn{3}{|c|}{ Top yield (t/fed) } & \multicolumn{3}{|c|}{ Sugar yield (t/fed) } \\
\hline & $2018 / 19$ & $2019 / 20$ & \multicolumn{2}{|c|}{ 2018/19 } & $2019 / 20$ & \multicolumn{2}{|l|}{ 2018/19 } & $2019 / 20$ \\
\hline \multicolumn{9}{|c|}{$\mathrm{N}$ fertilizer rates $\mathrm{kg} / \mathrm{fed}$} \\
\hline 60 & 20.634 & \multicolumn{2}{|l|}{20.859} & .532 & 9.436 & \multicolumn{2}{|l|}{3.790} & 3.832 \\
\hline 80 & 22.674 & \multicolumn{2}{|l|}{22.640} & 0.239 & 9.822 & \multicolumn{2}{|l|}{4.092} & 4.112 \\
\hline 100 & 22.901 & \multicolumn{2}{|l|}{22.789} & 0.958 & 10.267 & \multicolumn{2}{|l|}{3.975} & 3.993 \\
\hline Control & 22.058 & \multicolumn{2}{|l|}{21.985} & .955 & 9.713 & \multicolumn{2}{|l|}{3.987} & 3.966 \\
\hline F test & $* *$ & \multicolumn{2}{|l|}{$* *$} & $* *$ & $* *$ & $* *$ & & $* *$ \\
\hline LSD B at 0.05 & 0.380 & 0.369 & & 963 & 0.532 & 0.064 & & 0.052 \\
\hline Trait & $\begin{array}{c}\text { TS } \\
\text { \% }\end{array}$ & & & ose & & & $\begin{array}{r}\text { NUE of } \\
k\end{array}$ & $\begin{array}{l}\text { root yield } \\
/ \mathrm{kg}\end{array}$ \\
\hline Treatment & $2018 / 19$ & $2019 / 20$ & $2018 / 19$ & $2019 / 20$ & $2018 / 19$ & $2019 / 20$ & $2018 / 19$ & $2019 / 20$ \\
\hline $\mathrm{N}$ fertilizer rates $\mathrm{k}$ & fed & & & & & & & \\
\hline 60 & 21.49 & 21.80 & 18.37 & 18.37 & 85.49 & 84.30 & - & - \\
\hline 80 & 21.45 & 21.81 & 18.16 & 18.02 & 84.19 & 83.28 & 102.00 & 89.08 \\
\hline 100 & 21.57 & 21.75 & 17.53 & 17.62 & 80.54 & 80.56 & 56.67 & 48.27 \\
\hline Control & 21.84 & 21.98 & 18.04 & 18.04 & 82.77 & 82.09 & 35.60 & 28.17 \\
\hline F test & $* *$ & $* *$ & $* *$ & $* *$ & $* *$ & $* *$ & $* *$ & $* *$ \\
\hline LSD B at 0.05 & 0.10 & 0.11 & 0.13 & 0.16 & 0.82 & 0.58 & 3.43 & 2.51 \\
\hline
\end{tabular}

Table (3) also indicated that different slowrelease $\mathrm{N}$ fertilizer rates affected significantly nitrogen use efficiency NUE of root in both seasons. Fertilizing sugar beet with $80 \mathrm{~kg} \mathrm{~N} / \mathrm{fad}$ (as a mixture) increased NUE by 129.69 and $204.08 \%$ in the first season and by 125.12 and $223.60 \%$ in the second season, respectively, over $100 \mathrm{~kg} \mathrm{~N} /$ fad with and without urea formaldehyde. These increases due to mixing slowrelease nitrogen fertilizer may be attributed to minimizing the loss of nitrogen by leaching, retarded nitrification besides saving a suitable amount of nitrogen as plant need during the different stage life which increased growth and root yield was reflected on NUE. Similar finding was reported by Abdel-Wahab and El Manzlawy (2016), Zohry et al. (2017). Dou and Alva (1998) found that the total $\mathrm{N}$ uptake by seedlings was higher for the controlled release fertilizers than conventional urea.

Interaction effect between onion plant density and slow-release $\mathbf{N}$ fertilizer rate:

Root diameter, root weight/plant, root and sugar yields/fad and NUE for root yield were significantly affected by the interaction between sugar beet/onion intercropping pattern and slow-release $\mathrm{N}$ fertilizer rate in the second season, while quality traits of sugar beet (TSS $\%$, sucrose $\%$ and purity $\%$ ) were significantly affected in both seasons (Table, 4). Intercropped two rows of onion with sugar beet and fertilizing by mixed slow-release $\mathrm{N}$ at $100 \mathrm{~kg} /$ fad gained the highest values of root diameter and weight and root yield/fad, while the maximum sugar yield/fad and NUE produced by fertilizing the same pattern with the mix of $80 \mathrm{~kg}$ $\mathrm{N} /$ fad. Meanwhile, the lowest values of these traits achieved by sugar beet intercropping with four rows of onion and received $60 \mathrm{~kg} \mathrm{~N} / \mathrm{fad}$ for yield and yield components, but the same pattern fertilizing with control resulting in the lowest NUE. On the contrary, fertilizing sugar beet intercropped with two rows of onion with the highest $\mathrm{N}$ rate $100 \mathrm{k} /$ fad produced the lowest sucrose $\%$ and purity $\%$. These results hold true in both seasons.

The higher root weight was the less the TSS, sucrose and purity percentage were obtained. Results herein reveal that intercropping two rows of onion and sugar beet with application $\mathrm{N}$ fertilizer at $80 \mathrm{~kg} / \mathrm{fad}$ furnished suitable growth resources for sugar beet plants by reduced interspecific competition and this effect was increased sugar yield and NUE. These results are in accordance with those obtained by AbdelWahab and El Manzlawy (2016) who found that intercropping pattern of wheat/faba bean and slowrelease $\mathrm{N}$ fertilizer can be more effective in increasing yield, quality and $\mathrm{N}$ use efficiency. 
Table (4): The interaction effect between onion plant densities and slow-release $\mathrm{N}$ fertilizer rates on sugar beet characters in 2018/2019 and 2019/2020 seasons

\begin{tabular}{|c|c|c|c|c|c|c|c|c|c|}
\hline \multirow{2}{*}{ Treatmen } & \multirow[t]{2}{*}{ Trait } & \multicolumn{2}{|c|}{$\begin{array}{c}\text { Root diameter } \\
(\mathrm{cm})\end{array}$} & \multicolumn{2}{|c|}{$\begin{array}{c}\text { Root weight/plant } \\
\text { (g) }\end{array}$} & \multicolumn{2}{|c|}{$\begin{array}{c}\text { Root yield } \\
\text { (t/fed) }\end{array}$} & \multicolumn{2}{|c|}{$\begin{array}{c}\text { Sugar yield } \\
\text { (t/fed) }\end{array}$} \\
\hline & & $2018 / 19$ & $2019 / 20$ & 2018/19 & $2019 / 20$ & 2018/19 & $2019 / 20$ & 2018/19 & $2019 / 20$ \\
\hline \multirow{4}{*}{2 rows } & 60 & 8.84 & 9.63 & 687.00 & 731.67 & 21.627 & 22.052 & 3.958 & 4.011 \\
\hline & 80 & 10.31 & 11.30 & 755.14 & 761.67 & 24.242 & 24.377 & 4.315 & 4.386 \\
\hline & 100 & 11.09 & 12.20 & 763.23 & 786.67 & 24.403 & 24.455 & 4.175 & 4.247 \\
\hline & control & 9.55 & 11.17 & 724.21 & 738.33 & 22.886 & 23.472 & 4.119 & 4.237 \\
\hline \multirow{4}{*}{3 rows } & 60 & 8.31 & 9.37 & 649.00 & 701.67 & 20.495 & 20.917 & 3.777 & 3.870 \\
\hline & 80 & 9.74 & 10.90 & 731.84 & 745.00 & 22.330 & 22.652 & 4.074 & 4.172 \\
\hline & 100 & 9.47 & 10.60 & 735.96 & 758.33 & 22.672 & 22.968 & 3.960 & 4.047 \\
\hline & control & 9.15 & 10.43 & 708.25 & 721.67 & 22.102 & 22.047 & 3.993 & 3.977 \\
\hline \multirow{4}{*}{4 rows } & 60 & 7.85 & 9.10 & 628.20 & 628.33 & 19.781 & 19.607 & 3.634 & 3.614 \\
\hline & 80 & 9.43 & 10.47 & 715.65 & 706.67 & 21.451 & 20.892 & 3.886 & 3.777 \\
\hline & 100 & 9.43 & 10.33 & 722.78 & 705.00 & 21.628 & 20.945 & 3.790 & 3.684 \\
\hline & control & 8.89 & 10.00 & 705.13 & 648.33 & 21.187 & 20.437 & 3.850 & 3.685 \\
\hline \multicolumn{2}{|c|}{$F$ test } & N.S & $*$ & N.S & $*$ & N.S & $*$ & N.S & $*$ \\
\hline \multicolumn{2}{|c|}{ LSD B at 0.05} & N.S & 0.21 & N.S & 16.69 & N.S & 0.566 & N.S & 0.090 \\
\hline \multicolumn{10}{|c|}{ Table (4) Cont. } \\
\hline \multirow{2}{*}{\multicolumn{2}{|c|}{ Treatment }} & \multicolumn{2}{|c|}{$\begin{array}{c}\text { TSS } \\
\%\end{array}$} & \multicolumn{2}{|c|}{$\begin{array}{c}\text { Sucrose } \\
\%\end{array}$} & \multicolumn{2}{|c|}{$\begin{array}{c}\text { Purity } \\
\%\end{array}$} & \multicolumn{2}{|c|}{$\begin{array}{c}\text { NUE of root yield } \\
\mathrm{kg} / \mathrm{kg}\end{array}$} \\
\hline & & 2018/19 & 2019/20 & 2018/19 & $2019 / 20$ & 2018/19 & $2019 / 20$ & 2018/19 & $2019 / 20$ \\
\hline \multirow{4}{*}{$\begin{array}{c}2 \\
\text { rows }\end{array}$} & 60 & 21.80 & 22.03 & 18.30 & 18.19 & 83.94 & 82.57 & - & - \\
\hline & 80 & 21.57 & 21.77 & 17.80 & 17.99 & 82.52 & 82.65 & 130.75 & 116.25 \\
\hline & 100 & 21.83 & 21.86 & 17.11 & 17.37 & 78.37 & 79.44 & 69.40 & 60.08 \\
\hline & control & 21.93 & 22.27 & 18.00 & 18.05 & 82.08 & 81.05 & 31.48 & 35.50 \\
\hline \multirow{4}{*}{$\begin{array}{c}3 \\
\text { rows }\end{array}$} & 60 & 21.53 & 21.97 & 18.43 & 18.50 & 85.60 & 84.21 & - & - \\
\hline & 80 & 21.37 & 21.96 & 18.24 & 18.42 & 85.37 & 83.87 & 91.75 & 86.75 \\
\hline & 100 & 21.37 & 21.70 & 17.47 & 17.62 & 81.73 & 81.20 & 54.43 & 51.28 \\
\hline & control & 21.90 & 21.73 & 18.07 & 18.04 & 82.49 & 83.01 & 40.18 & 28.25 \\
\hline \multirow{4}{*}{$\begin{array}{c}4 \\
\text { rows }\end{array}$} & 60 & 21.13 & 21.40 & 18.37 & 18.43 & 86.94 & 86.12 & - & - \\
\hline & 80 & 21.40 & 21.70 & 18.12 & 18.08 & 84.67 & 83.32 & 83.50 & 64.25 \\
\hline & 100 & 21.50 & 21.70 & 17.52 & 17.59 & 81.51 & 81.05 & 46.18 & 33.45 \\
\hline & control & 21.70 & 21.93 & 18.17 & 18.03 & 83.74 & 82.22 & 35.15 & 20.75 \\
\hline \multicolumn{2}{|l|}{ F test } & $* *$ & $* *$ & $* *$ & $*$ & $*$ & $* *$ & N.S & $*$ \\
\hline \multicolumn{2}{|c|}{ LSD B at 0.05} & 0.18 & 0.17 & 0.23 & 0.27 & 1.42 & 1.01 & N.S & 4.35 \\
\hline
\end{tabular}

Onion yield and its attributes:

\section{Effect of onion plant densities:}

Data in Table (5) indicated that growth, yield and its attributes of onion in solid culture out yielded that those recorded under any intercropping patterns. Plant height, number of leaves/plant, bulb diameter, bulb weight and yield/fad of onion were significant effect by plant density of onion in both seasons. The highest values of plant height $(67.07$ and $68.44 \mathrm{~cm})$ in the first and second seasons, respectively, were obtained by intercropping four rows of onion with sugar beet, while the shortest plants were obtained by decreased onion plant density to two rows intercropped with sugar beet. Plant to plant competition for light intercepted by foliage might be the cause to length onion height. These results were in accordance with those obtained by Ibrahim et al (2005). The same table showed that the number of leaves/plant and yield components of onion, followed the reversed trend. There were gradual increases in the values of number of leaves/plant, bulb diameter and bulb weight with decreasing onion plant density intercropped with sugar beet from four rows to three and two rows in two growing seasons. This tendency of the intercropping treatments effects was also due to the low below and above ground competition for light intercepted by foliage. 
Yield/fad was governed by plant density of onion per unit area of land, rather than the yield of the individual plant (expressed in bulb weight). Significant increases in onion yield/fad were evident with an increases plant density of onion intercropped with sugar beet from two up to four rows. Intercropped four rows of onion with sugar beet out yielded other intercropping patterns. The excesses were estimated by 17.44 and $20.02 \%$ over 2 rows of onion intercropped with sugar beet, in first and second seasons, respectively. These results were true in both seasons and were supported by Besheit et al. (2002), Ibrahim et al. (2005) and Abdel Motagally and Metwally (2014).

Concerning nitrogen use efficiency $(\mathrm{kg} / \mathrm{kg})$, results in Table (5) clear indicated that intercropping patterns of onion with sugar beet significantly effect on NUE in both seasons. The highest values of NUE were obtained by intercropped two rows of onion with sugar beet, whereas the lowest values were detected with increased onion density to four rows intercropped with sugar beet. These results could be due to the low plant density of onion decreased intra and inter-specific competition between the same and different species, respectively, for basic growth resources. This result accordance with those obtained by Abdelkader and Mohsen (2016) they found that total nitrogen and phosphorus, as well as potassium uptake per onion plant (g), were significantly affected by the intercropping pattern in both seasons.

Table (5): Effect of onion plant densities on onion characters in 2018/2019 and 2019/2020 seasons

\begin{tabular}{|c|c|c|c|c|c|c|}
\hline \multirow{2}{*}{ Treatment } & \multicolumn{2}{|c|}{$\begin{array}{l}\text { Plant height } \\
\text { (cm) }\end{array}$} & \multicolumn{2}{|c|}{$\begin{array}{l}\text { No. of leaves/ } \\
\text { Plant }\end{array}$} & \multicolumn{2}{|c|}{$\begin{array}{l}\text { Bulb diameter } \\
\text { (cm) }\end{array}$} \\
\hline & $2018 / 19$ & $2019 / 20$ & $2018 / 19$ & $2019 / 20$ & 2018/19 & $2019 / 20$ \\
\hline \multicolumn{7}{|l|}{ Onion plant densities } \\
\hline 2 rows & 58.30 & 63.93 & 8.30 & 9.31 & 3.73 & 4.89 \\
\hline 3 rows & 64.34 & 66.04 & 7.17 & 8.83 & 3.44 & 4.31 \\
\hline 4 rows & 67.07 & 68.44 & 5.60 & 8.95 & 2.78 & 3.30 \\
\hline F test & $* *$ & $* *$ & $* *$ & $*$ & $* *$ & $* *$ \\
\hline LSD A at 0.05 & 0.81 & 0.32 & 0.25 & 0.14 & 0.11 & 0.1 \\
\hline Solid culture & 82.23 & 80.83 & 8.83 & 10.01 & 11.32 & 10.31 \\
\hline \multirow{2}{*}{ Treatment } & \multicolumn{2}{|c|}{$\begin{array}{c}\text { Bulb weight } \\
\text { (g) }\end{array}$} & \multicolumn{2}{|c|}{$\begin{array}{c}\text { Onion yield } \\
\text { (t/fad) }\end{array}$} & \multicolumn{2}{|c|}{$\begin{array}{c}\text { NUE } \\
(\mathrm{kg} / \mathrm{kg}) \\
\end{array}$} \\
\hline & 2018/19 & $2019 / 20$ & 2018/19 & $2019 / 20$ & 2018/19 & $2019 / 20$ \\
\hline \multicolumn{7}{|l|}{ Onion plant densities } \\
\hline 2 rows & 52.88 & 70.00 & 4.133 & 4.591 & 38.59 & 42.91 \\
\hline 3 rows & 43.11 & 55.80 & 4.710 & 5.337 & 38.48 & 31.20 \\
\hline 4 rows & 34.43 & 43.01 & 4.854 & 5.510 & 20.08 & 24.72 \\
\hline F test & $* *$ & $* *$ & $* *$ & $* *$ & $*$ & $* *$ \\
\hline LSD A at 0.05 & 1.50 & 1.60 & 0.199 & 0.280 & 2.05 & 2.48 \\
\hline Solid culture & 64.23 & 69.24 & 12.650 & 13.000 & - & - \\
\hline
\end{tabular}

\section{Effect of slow-release $\mathbf{N}$ fertilizer rates:}

Results in Table (6) showed that growth, yield and its components of onion were significantly affected by slow-release $\mathrm{N}$ fertilizer rates in both seasons. Data revealed that increasing nitrogen rate from 60 up to $100 \mathrm{~kg} \mathrm{~N} / \mathrm{fad}$ with or without urea formaldehyde gradually increased plant height, number of leaves/plant, individual bulb diameter and weight and onion yield/fad as well as NUE. It is worth note that, differences between fertilizer blends at 100 and $80 \mathrm{~kg}$ $\mathrm{N} /$ fad was failed to reach the level of significance in both seasons. The highest increase in yield (ton/fad) owing to $100 \mathrm{~kg} \mathrm{~N} /$ fad (as mixture fertilizer) were $16.79,1.51$ and $12.70 \%$ in the first season and being $13.37,1.72$ and $8.65 \%$ in the second season, compared to at $60,80 \mathrm{~kg} \mathrm{~N} / \mathrm{fad}$ and control treatment, respectively. The increase in onion yield due to slowrelease as a nitrogen source might be attributed to its increased the nutrients availability and improved efficiency uptake, thus increased crop growth rate resulted in raising individual bulb weight and diameter, therefore, increased yield per faddan. These results are in an agreement with those recorded by Bahr et al. (2006), Ahmed et al. (2007). Drost and Koenig (2002) showed a reduction of $\mathrm{N}$ applied from 224 to $168 \mathrm{~kg} / \mathrm{ha}$ had little effect on yield, although a further reduction to $112 \mathrm{~kg} / \mathrm{ha}$ did significantly reduce bulb yield when the entire $\mathrm{N}$ was supplied from polymer-coated urea (PU).

Significant differences in nitrogen use efficiency NUE was noticed owing to slow-release $\mathrm{N}$ fertilizer in both seasons as shown in Table (6). Blends urea formaldehyde with traditional urea highly increased $\mathrm{N}$ use efficiency compared to tradition urea. The highest values of NUE ( 57.83 and $58.59 \mathrm{~kg}$ onion $/ \mathrm{kg} \mathrm{N}$ ) were resulted from the application of slow-release $\mathrm{N}$ fertilizer at $80 \mathrm{~kg} \mathrm{~N} / \mathrm{fad}$, while the control (100 kg $\mathrm{N} /$ fad as traditional urea) produced the lowest NUE 8.35 and 9.14 in first and second seasons, respectively. 
The negative result of control applied on NUE could be due to quick release of nitrogen fertilizer is lost easily from sandy soils, hence $\mathrm{N}$ availability did not satisfy onion requirement for growth and development. Urea formaldehyde as slow-release nitrogen fertilizer has many advantages over traditional urea, including a reduction in labour with a single basal application and higher nitrogen uptake efficiency by crops (Shoji and Gandeza, 1992; Zohry et al., 2017). It is also environment friendly in terms of reduction of fertilizer,

Table (6): Effect of slow-release N fertilizer rates on onion characters in two growing seasons 2018/2019 and 2019/2020

\begin{tabular}{|c|c|c|c|c|c|c|}
\hline \multirow{2}{*}{ Treatment } & \multicolumn{2}{|c|}{$\begin{array}{l}\text { Plant height } \\
\text { (cm) }\end{array}$} & \multicolumn{2}{|c|}{ No. of leaves/ Plant } & \multicolumn{2}{|c|}{$\begin{array}{c}\text { Bulb diameter } \\
(\mathrm{cm})\end{array}$} \\
\hline & $2018 / 19$ & $2019 / 20$ & 2018/19 & $2019 / 20$ & $2018 / 19$ & $2019 / 20$ \\
\hline \multicolumn{7}{|c|}{$\mathrm{N}$ fertilizer rates $\mathrm{kg} / \mathrm{fed}$} \\
\hline 60 & 59.89 & 63.77 & 6.60 & 8.93 & 3.11 & 3.92 \\
\hline 80 & 61.69 & 66.49 & 7.10 & 9.06 & 3.37 & 4.19 \\
\hline 100 & 67.21 & 68.01 & 7.43 & 9.31 & 3.51 & 4.56 \\
\hline Control & 64.16 & 66.29 & 6.96 & 8.81 & 3.28 & 4.00 \\
\hline F test & $* *$ & $* *$ & $* *$ & $* *$ & $* *$ & $* *$ \\
\hline LSD B at 0.05 & 0.76 & 0.63 & 0.15 & 0.11 & 0.15 & 0.14 \\
\hline \multirow{2}{*}{ Treatment } & \multicolumn{2}{|c|}{$\begin{array}{c}\text { Bulb weight } \\
\text { (g) }\end{array}$} & \multicolumn{2}{|c|}{$\begin{array}{c}\text { Onion yield } \\
\text { (t/fad) }\end{array}$} & \multicolumn{2}{|c|}{$\begin{array}{c}\text { NUE } \\
(\mathrm{kg} / \mathrm{kg}) \\
\end{array}$} \\
\hline & $2018 / 19$ & $2019 / 20$ & $2018 / 19$ & $2019 / 20$ & $2018 / 19$ & $2019 / 20$ \\
\hline \multicolumn{7}{|c|}{$\mathrm{N}$ fertilizer rates $\mathrm{kg} / \mathrm{fed}$} \\
\hline 60 & 38.78 & 51.51 & 4.194 & 4.796 & - & - \\
\hline 80 & 43.63 & 56.98 & 4.825 & 5.345 & 57.83 & 58.59 \\
\hline 100 & 49.81 & 57.89 & 4.898 & 5.437 & 30.99 & 31.10 \\
\hline Control & 41.68 & 53.37 & 4.346 & 5.004 & 8.35 & 9.14 \\
\hline F test & $* *$ & $* *$ & $* *$ & $* *$ & $* *$ & $* *$ \\
\hline LSD B at 0.05 & 1.48 & 2.57 & 0.121 & 0.197 & 1.36 & 1.96 \\
\hline
\end{tabular}

$\mathrm{N}$ losses associated with leaching and denitrification (Ueno and Yamamuro, 1996). Soil sampling indicated that more $\mathrm{N}$ was retained in polymer urea (PU) treated onion beds than in urea-treated beds, which improved nitrogen use efficiency. Also, $\mathrm{N}$ use efficiency improved when there was more PU in the blend and when PU was compared with urea at the same rate (Drost and Koenig, 2002).

Interaction effect between onion plant densities and slow-release $\mathbf{N}$ fertilizer rate:

Data illustrated in Table (7) indicated that interaction between onion plant density and slowrelease $\mathrm{N}$ fertilizer were significant effect on plant height, the number of leaves/plant, bulb diameter and onion yield per fadden as well as NUE $(\mathrm{kg} / \mathrm{kg})$ in the first season, only. The highest plant height and onion yield ton/fad were produced by intercropping sugar beet with four rows of onion that received $100 \mathrm{~kg}$ $\mathrm{N} /$ fad as mixture fertilizer, while the lowest values for these traits detected owing to low onion plant density intercropping with sugar beet ( 2 rows of the onion) and fertilizing by mixture fertilizer at $60 \mathrm{~kg} \mathrm{~N} / \mathrm{fad}$. These results were expected since onion yield/fad positively correlated with the number of plants per unit area and this effect was increased by the application of slow- release $\mathrm{N}$ fertilizer at $100 \mathrm{~kg} / \mathrm{fad}$, which could be provided with a constant supply of $\mathrm{N}$ to roots of onion plants under sandy soil conditions. The same table showed that the highest values of the number of leaves/plant and bulb diameter achieved with low onion plant density (2 rows) intercropped with sugar beet beside increase slow-release $\mathrm{N}$ fertilizer rate up to $100 \mathrm{~kg} / \mathrm{fad}$ in two growing seasons. This tendency of the interaction effects was also due to the low below and above the ground competition for light intercepted by foliage and nutrients.

With regard to NUE, there was a significant effect for the interaction of onion plant density with slow-release $\mathrm{N}$ fertilizer rate on nitrogen use efficiency in the first season (Table 7). Intercropping three rows of onion and application slow-release $\mathrm{N}$ fertilizer at 80 $\mathrm{kg} /$ fad was resulting in the highest NUE $67.70 \mathrm{~kg} / \mathrm{kg}$, followed by $64.83 \mathrm{~kg} / \mathrm{kg}$. Which was produced by fertilizing two rows of onion intercropped with sugar beet and application the same $\mathrm{N}$ fertilizer rate, even if differences between two and three rows of onion plant density failed to reach the level of significance. While intercropped four rows of onion with sugar beet and fertilizing with control was resulting in the lowest NUE $3.67 \mathrm{~kg} / \mathrm{kg}$. 
Table (7): The interaction effect between onion plant densities and slow-release $\mathrm{N}$ fertilizer rates on onion characters in 2018/2019 and 2019/2020 seasons

\begin{tabular}{|c|c|c|c|c|c|c|c|c|c|c|c|}
\hline \multirow{2}{*}{ Treatmer } & \multirow{2}{*}{ Trait } & \multicolumn{2}{|c|}{$\begin{array}{l}\text { Plant height } \\
\text { (cm) }\end{array}$} & \multicolumn{2}{|c|}{$\begin{array}{c}\text { No. of } \\
\text { leaves/plant }\end{array}$} & \multicolumn{2}{|c|}{$\begin{array}{l}\text { Bulb diameter } \\
(\mathrm{cm})\end{array}$} & \multicolumn{2}{|c|}{$\begin{array}{c}\text { Onion yield } \\
(\mathrm{t} / \mathrm{fad})\end{array}$} & \multicolumn{2}{|c|}{$\begin{array}{c}\text { NUE } \\
(\mathrm{kg} / \mathrm{kg})\end{array}$} \\
\hline & & 2018/19 & 2019/20 & 2018/19 & $2019 / 20$ & 2018/19 & 2019/20 & 2018/19 & 2019/20 & 2018/19 & 2019/20 \\
\hline \multirow{4}{*}{2 rows } & 60 & 54.13 & 60.77 & 8.13 & 9.20 & 45.03 & 61.90 & 3.859 & 4.295 & - & - \\
\hline & 80 & 56.77 & 64.10 & 8.33 & 9.37 & 53.97 & 68.50 & 4.293 & 4.837 & 64.83 & 80.90 \\
\hline & 100 & 62.10 & 65.87 & 8.50 & 9.57 & 62.50 & 69.60 & 4.375 & 4.904 & 38.51 & 45.45 \\
\hline & Control & 60.20 & 65.00 & 8.23 & 9.10 & 50.03 & 64.00 & 4.006 & 4.327 & 12.44 & 2.39 \\
\hline \multirow{4}{*}{3 rows } & 60 & 61.03 & 63.63 & 6.67 & 8.63 & 38.90 & 52.30 & 4.187 & 4.996 & - & - \\
\hline & 80 & 62.93 & 66.67 & 7.20 & 8.83 & 41.57 & 57.30 & 5.098 & 5.503 & 67.70 & 50.70 \\
\hline & 100 & 68.40 & 67.80 & 7.67 & 9.10 & 50.07 & 58.90 & 5.157 & 5.603 & 38.82 & 30.35 \\
\hline & Control & 65.00 & 66.07 & 7.13 & 8.73 & 41.90 & 54.70 & 4.399 & 5.247 & 8.93 & 12.55 \\
\hline \multirow{4}{*}{4 rows } & 60 & 64.50 & 66.90 & 5.00 & 8.97 & 32.40 & 40.33 & 4.536 & 5.104 & - & - \\
\hline & 80 & 65.37 & 68.70 & 5.77 & 8.97 & 35.37 & 45.13 & 5.085 & 5.696 & 40.95 & 44.18 \\
\hline & 100 & 71.13 & 70.37 & 6.13 & 9.27 & 36.87 & 45.17 & 5.161 & 5.804 & 15.63 & 17.50 \\
\hline & Control & 67.28 & 67.80 & 5.50 & 8.60 & 33.10 & 41.40 & 4.634 & 5.437 & 3.67 & 12.47 \\
\hline \multicolumn{2}{|l|}{$F$ test } & $*$ & N.S & $*$ & N.S & $* *$ & N.S & $*$ & N.S & $*$ & N.S \\
\hline \multicolumn{2}{|c|}{ LSD B at 0.05} & 1.10 & N.S & 0.26 & N.S & 2.56 & N.S & 0.209 & N.S & 2.35 & N.S \\
\hline
\end{tabular}

\section{Nematode parameters assessment:}

Results in Table (8) indicated that there were significant differences among all treatments in reducing nematode population under field conditions. In general, the nematode parameters negatively correlated with intercropping onion with sugar beet compared to check treatment (solid sugar beet). Data in two seasons were almost identical. The most effective treatment in reducing the number of galls or eggmasses per root system, root gall index (RGI) or eggmasses index (EI), as well as, number of second stage juveniles $\left(\mathrm{j}_{2}\right)$ in soil was the treatment the nematicide Vydate ${ }^{\circledR}$ (oxamyl) compared to solid sugar beet in two successive seasons. The second most effective treatment in reducing root-knot nematodes, Meloidogyne spp., the number was 4rows with $80 \mathrm{~kg}$ nitrogen in two successive seasons. Results are in agreement with (Li et al., 2018) who showed that, when cucumber has grown with welsh onion as a companion plant, cucumber roots reduced root galls and egg-masses than the control cucumber roots. The same trend was noticed by Abdel-Baset (2007) who reported that intercropping onion with green bean reduced the root-knot nematode, $M$. incongita reproduction in the greenhouse. Reducing nematode populations may due to onion root exudates consist of a variety of compounds, for example, hexahydro-3-(2methylpropyl)-pyrrolo[1,2-a]pyrazine-1,4-dione, $\mathrm{N}$ formyl-tyramine, dibutyl phthalate or hexahydro-3(phenylmethyl)- pyrrolo[1,2-a] pyrazine-1,4-dione, which involved in inhibition of root-knot nematodes activity and egg hatchability. The exudate compounds may likely have a complex interrelationship on resistance against root-knot nematodes ( $\mathrm{Li}$ et al., 2018).
Also, the same table showed that increasing slow-release $\mathrm{N}$ fertilizer rate up to $80 \mathrm{~kg} \mathrm{~N} / \mathrm{fad}$ significantly reduced nematode reproduction. Application of urea at a dose of $150 \mathrm{unit} / \mathrm{fad}$ significantly reduced reproduction of $M$. arenaria infesting sugar beet under field conditions (Ismail and Mohamed, 2012). Previous studies showed that urea and ammonia-releasing fertilizers are effective in controlling many plant parasitic nematodes (Mojtahedi and Lownsberry, 1976). Indeed, urea and nitrogenous fertilizers are considered to be good nematicides when applied at levels over 300 and $150 \mathrm{~kg} \mathrm{~N} / \mathrm{ha}$ soil, respectively (Rodriguez-Kabana, 1986; Alam, 1992). Urea is readily converted to ammonia $\left(\mathrm{NH}_{3}\right)$ by urease present in the soil. This conversion is necessary if urea is to be effective both as a fertilizer and as a nematicide (Rodriguez-Kabana, 1986). The nematicidal properties of ammonia could be attributed to; (1) its plasmolysing effect in the immediate vicinity of its application site in the soil, and (2) the possibility that ammonia could exert a selective influence for microbial antagonists of nematodes, particularly fungi (Rodriguez-Kabana, 1986; Santana-Gomes et al., 2013).

The research approach of using nitrogenous fertilizers to decrease nematodes and maximize the benefits of the fertilizers. Oteifa (1955) reported that ammonia ions released during the degradation of urea decreased the counts of $M$. incognita females and eggmasses produced on infected lima bean. The role of nitrogenous fertilizers, especially urea in the hindrance of nematodes and improving the growth of treated plants was also reported (Noweer and Hassabo, 2005; El-Shereif et al., 2008; Ismail and Mohamed, 2012). 
Table (8): Effect of onion plant densities intercropped with sugar beet and slow-release $\mathrm{N}$ fertilizer rates on root-knot nematodes Meloidogyne spp., in both seasons

\begin{tabular}{|c|c|c|c|c|c|c|c|c|c|c|c|}
\hline \multirow{2}{*}{\multicolumn{2}{|c|}{ Treatment }} & \multicolumn{2}{|c|}{$\begin{array}{c}\text { Number of } \\
\text { galls/root system }\end{array}$} & \multicolumn{2}{|c|}{ RGI } & \multicolumn{2}{|c|}{$\begin{array}{l}\text { Number of } \\
\text { egg-masses / } \\
\text { root system }\end{array}$} & \multicolumn{2}{|c|}{ EI } & \multicolumn{2}{|c|}{$\begin{array}{c}\text { Number of } \mathbf{J}_{2 \mathrm{~S}} / \\
250 \mathrm{gm} \text { soil }\end{array}$} \\
\hline & & 2018/19 & $2019 / 20$ & 2018/19 & $2019 / 20$ & 2018/19 & $2019 / 20$ & 2018/19 & $2019 / 20$ & 2018/19 & $2019 / 20$ \\
\hline \multirow{3}{*}{2 rows } & 60 & 95.67 & 91.33 & 4 & 4 & 42.33 & 40.67 & 3 & 3 & 346.67 & 306.67 \\
\hline & 80 & 58.67 & 57.33 & 4 & 4 & 27.33 & 25.00 & 3 & 3 & 156.67 & 126.67 \\
\hline & 100 & 62.33 & 71.33 & 4 & 4 & 39.67 & 40.67 & 3 & 3 & 266.67 & 246.00 \\
\hline \multirow{3}{*}{ Mean } & Control & 82.33 & 74.33 & 4 & 4 & 38.00 & 36.00 & 3 & 3 & 300.00 & 281.67 \\
\hline & & 74.75 & 73.58 & 4 & 4 & 36.83 & 35.59 & 3 & 3 & 267.50 & 240.25 \\
\hline & 60 & 48.67 & 46.67 & 4 & 4 & 30.00 & 31.00 & 3 & 3 & 260.00 & 245.00 \\
\hline \multirow{2}{*}{3 rows } & 80 & 48.93 & 39.67 & 4 & 4 & 20.48 & 18.00 & 3 & 3 & 166.44 & 136.25 \\
\hline & 100 & 55.00 & 36.67 & 4 & 4 & 22.33 & 24.33 & 3 & 3 & 166.67 & 163.33 \\
\hline \multirow{3}{*}{ Mean } & Control & 56.44 & 55.77 & 4 & 4 & 23.50 & 24.00 & 3 & 3 & 206.67 & 193.33 \\
\hline & & 52.26 & 44.70 & 4 & 4 & 24.08 & 24.33 & 3 & 3 & 199.95 & 184.48 \\
\hline & 60 & 45.67 & 32.67 & 4 & 4 & 19.94 & 23.67 & 3 & 3 & 176.67 & 155.00 \\
\hline \multirow{3}{*}{4 rows } & 80 & 32.33 & 30.67 & 4 & 3 & 11.00 & 9.67 & 3 & 2 & 86.67 & 80.00 \\
\hline & 100 & 37.67 & 30.67 & 4 & 3 & 16.00 & 19.67 & 3 & 3 & 136.67 & 130.00 \\
\hline & Control & 56.69 & 55.38 & 4 & 4 & 28.30 & 26.70 & 3 & 3 & 156.67 & 126.67 \\
\hline \multicolumn{2}{|l|}{ Mean } & 43.09 & 37.35 & 4 & 3.5 & 18.81 & 19.93 & 3 & 3 & 139.17 & 122.92 \\
\hline \multicolumn{2}{|c|}{ Mean of $60 \mathrm{~kg} \mathrm{~N} / \mathrm{f}$} & 63.34 & 56.89 & 4 & 4 & 30.76 & 31.78 & 3 & 3 & 261.11 & 235.56 \\
\hline \multicolumn{2}{|c|}{ Mean of $80 \mathrm{~kg} \mathrm{~N} / \mathrm{f}$} & 46.64 & 42.56 & 4 & 4 & 19.60 & 17.56 & 3 & 3 & 136.59 & 114.31 \\
\hline \multicolumn{2}{|c|}{ Mean of $100 \mathrm{~kg} \mathrm{~N} / \mathrm{f}$} & 51.67 & 46.22 & 4 & 4 & 26.00 & 28.22 & 3 & 3 & 190.00 & 179.78 \\
\hline \multicolumn{2}{|c|}{ Mean of control } & 65.15 & 61.83 & 4 & 4 & 29.93 & 28.90 & 3 & 3 & 221.11 & 200.56 \\
\hline \multicolumn{2}{|c|}{ LSD at $0.05 \mathrm{~A}$} & 1.59 & 3.12 & - & - & 2.17 & 2.03 & - & - & 14.01 & 13.44 \\
\hline \multicolumn{2}{|c|}{ LSD at $0.05 \mathrm{~B}$} & 4.62 & 2.48 & - & - & 1.88 & 1.75 & - & - & 20.42 & 14.87 \\
\hline \multicolumn{2}{|c|}{ LSD at $0.05 \mathrm{~A} \times \mathrm{B}$} & 8.00 & 4.29 & - & - & 3.26 & 3.03 & - & - & 35.37 & 25.75 \\
\hline \multicolumn{2}{|c|}{$\begin{array}{l}\text { Solid sugar beet } \\
\text { Without nematcide }\end{array}$} & 155.00 & 168.67 & 5 & 5 & 68.33 & 68.00 & 4 & 4 & 760.00 & 720.00 \\
\hline \multicolumn{2}{|c|}{$\begin{array}{l}\text { Solid sugar beet } \\
\text { with Vydate® }\end{array}$} & 11.00 & 9.67 & 3 & 2 & 2.00 & 2.00 & 1 & 1 & 66.67 & 53.33 \\
\hline
\end{tabular}

* Root gall index (RGI) or egg masses index (EI) was determined according to Taylor \& Sasser (1978)

\section{Competitive relationships}

\section{Land equivalent ratio:}

Land equivalent ratio (LER) was used to compares the yields from growing two crops together with yields from growing the same crops in solid culture (Mead and Willey, 1980). Results in Table (9) show clearly that the averaged values of LER ratios of onion plant density $\mathrm{x}$ slow-release $\mathrm{N}$-fertilizer treatments were greater than 1.0 indicating that intercropping gave advantages in land use which means the actual productivity was higher than expected. Data also point out that the means of the relative yield of sugar beet (RYs) were ever higher than those of the relative yield of onion (RYo) indicated that relative yield positively correlated with plant density per unit area. The land equivalent ratio of intercropping two onion rows with sugar beet surpassed the other two intercropping patterns (three and four rows of onion with sugar beet) in both seasons. It is obvious from the same table that increasing $\mathrm{N}$ fertilizer from 60 up to $100 \mathrm{~kg} / \mathrm{fad}$ gradually increased relative yield of both crops and LER. The highest LER (1.326 and 1.349) were produced by intercropping two rows of onion with sugar beet that received blends fertilizer at $100 \mathrm{~kg}$ $\mathrm{N} /$ fad in first and second seasons, respectively. Meanwhile, the lowest LER values (1.153 and 1.172) were achieved by fertilizing sugar beet/onion intercropping pattern (four rows) with low nitrogen rate $60 \mathrm{~kg} / \mathrm{fad}$, respectively in first and second seasons. Decreasing plant density of intercropped onion from four to two rows could be decreased intra and interspecific competition between two spices crops for basic growth resources, consequently formed suitable above and under-ground conditions for growth and development of both crops. Beside of the application of high rate of slow-release fertilizer provided a constant supply of $\mathrm{N}$ to plant roots under sandy soil conditions. These results are in harmony with those obtained by Abdel-Wahab and El Manzlawy (2016) who found that decreasing wheat density from 6 to 4 rows intercropping with faba bean with increasing $\mathrm{N}$ slowrelease fertilizer to $238 \mathrm{~kg} /$ ha gradually increased LER. These results confirmed by Zohry et al. (2017).

\section{Relative crowding coefficient (RCC):}

Relative crowding coefficient $(\mathrm{K})$ is the measure of the relative dominance of one species over the other in intercropping (Dewit, 1960). When the product of 
two coefficients ( $\mathrm{K}$ sugar $\mathrm{x} K$ onion) is greater than one, there is a yield advantage, if the value of $\mathrm{K}$ is one there is no yield advantage and if less than one there is no yield advantage and the system has the disadvantage (Khan et al., 2001). Average values of sugar beet (K sugar) exceeded those of onion indicating that sugar beet was a good competitor and the dominant component, whereas onion was the dominated (Table 9). Results on the relative crowding coefficient (K) showed higher values more than unity for the intercropping patterns (two rows of onion) and application slow-release $\mathrm{N}$ fertilizer rate at $100 \mathrm{~kg} / \mathrm{fad}$, which were 25.70 and 21.22 in first and second season, respectively. This indicated the clear yield advantage owing to intercropping two rows of onion with sugar beet. Results herein were in accordance with those obtained by Abdel Motagally and Metwally (2014), Masri and Safina (2015).

Table (9): The interaction effect between plant densities of onion and slow-release $\mathrm{N}$ fertilizer rates on competitive relationships in 2018/2019 and 2019/2020 seasons

\begin{tabular}{|c|c|c|c|c|c|c|c|c|c|}
\hline \multirow{2}{*}{$\begin{array}{c}\text { Treatment } \\
\text { Onion } \\
\text { Density }\end{array}$} & \multirow{2}{*}{$\begin{array}{l}\text { Trait } \\
\begin{array}{c}\text { N Ferti. } \\
\text { Rate }\end{array}\end{array}$} & \multicolumn{3}{|c|}{ Land equivalent ratio } & \multicolumn{3}{|c|}{ Crowding coefficient relative } & \multirow{2}{*}{$\begin{array}{c}\text { Gross } \\
\text { return } \\
\text { L.E/fad }\end{array}$} & \multirow{2}{*}{$\begin{array}{c}\text { Net } \\
\text { return } \\
\text { L.E/fad }\end{array}$} \\
\hline & & RY sugar & RY onion & LER & k sugar & k onion & $\mathbf{K}$ & & \\
\hline & & \multicolumn{8}{|c|}{ 2018/2019 season } \\
\hline \multirow{4}{*}{2 rows } & 60 & 0.868 & 0.305 & 1.173 & 2.20 & 1.32 & 2.90 & 18964 & 8861 \\
\hline & 80 & 0.973 & 0.339 & 1.313 & 12.19 & 1.54 & 18.78 & 21192 & 10840 \\
\hline & 100 & 0.980 & 0.346 & 1.326 & 16.20 & 1.59 & 25.70 & 21440 & 10438 \\
\hline & control & 0.919 & 0.317 & 1.236 & 3.78 & 1.39 & 5.25 & 19913 & 9996 \\
\hline \multirow{4}{*}{3 rows } & 60 & 0.823 & 0.331 & 1.154 & 2.29 & 1.00 & 2.30 & 19031 & 8281 \\
\hline & 80 & 0.897 & 0.403 & 1.300 & 4.27 & 1.37 & 5.85 & 21808 & 10552 \\
\hline & 100 & 0.910 & 0.408 & 1.318 & 5.00 & 1.40 & 6.99 & 22103 & 10342 \\
\hline & control & 0.887 & 0.348 & 1.235 & 3.88 & 1.08 & 4.20 & 20291 & 9751 \\
\hline \multirow{4}{*}{4 rows } & 60 & 0.794 & 0.359 & 1.153 & 2.57 & 0.84 & 2.16 & 19358 & 7961 \\
\hline & 80 & 0.861 & 0.402 & 1.263 & 4.14 & 1.01 & 4.17 & 21325 & 9366 \\
\hline & 100 & 0.868 & 0.408 & 1.276 & 4.40 & 1.03 & 4.55 & 21569 & 9048 \\
\hline & control & 0.851 & 0.366 & 1.217 & 3.80 & 0.87 & 3.29 & 20285 & 9121 \\
\hline \multicolumn{2}{|c|}{ Solid sugar beet } & 1.000 & - & 1.000 & & & & 15441 & 6828 \\
\hline & & \multicolumn{8}{|c|}{$2019 / 2020$ season } \\
\hline \multirow{4}{*}{2 rows } & 60 & 0.877 & 0.330 & 1.207 & 2.37 & 1.48 & 3.51 & 20057 & 9954 \\
\hline & 80 & 0.969 & 0.372 & 1.341 & 10.47 & 1.78 & 18.61 & 22350 & 11998 \\
\hline & 100 & 0.972 & 0.377 & 1.349 & 11.68 & 1.82 & 21.22 & 22525 & 11523 \\
\hline & control & 0.933 & 0.333 & 1.266 & 4.65 & 1.50 & 6.97 & 20859 & 10942 \\
\hline \multirow{4}{*}{3 rows } & 60 & 0.832 & 0.384 & 1.216 & 2.43 & 1.27 & 3.08 & 20869 & 10119 \\
\hline & 80 & 0.901 & 0.423 & 1.324 & 4.46 & 1.49 & 6.65 & 22785 & 11530 \\
\hline & 100 & 0.913 & 0.431 & 1.344 & 5.18 & 1.54 & 7.96 & 23149 & 11388 \\
\hline & control & 0.877 & 0.404 & 1.280 & 3.50 & 1.37 & 4.80 & 21958 & 11418 \\
\hline \multirow{5}{*}{4 rows } & 60 & 0.780 & 0.393 & 1.172 & 2.36 & 0.97 & 2.29 & 20404 & 9007 \\
\hline & 80 & 0.831 & 0.438 & 1.269 & 3.27 & 1.17 & 3.82 & 22256 & 10297 \\
\hline & 100 & 0.833 & 0.446 & 1.279 & 3.32 & 1.21 & 4.01 & 22499 & 9979 \\
\hline & control & 0.813 & 0.418 & 1.231 & 2.89 & 1.08 & 3.12 & 21501 & 10337 \\
\hline & ar beet & 1.000 & - & 1.000 & & & & 15595 & 6982 \\
\hline
\end{tabular}

Price of sugar beet was (520 LE. per ton) and price of onion (2000 LE per ton). Price of kg TU was 2.0 L.E. and UF was 10.0 LE.

Fixed cost of solid sugar beet was 8613 L.E. per fad, while intercropping onion with sugar beet increased variable cost of intercropping from 1244 to 3034 L.E. per fad.

\section{Economic evaluation:}

\section{Gross and net return/fad:}

The evaluation of different intercropping treatments was made for the two seasons as a gross and net return of the two components comparative with solid sugar beet as the main crop as shown in Table (9). Intercropped three rows of onion with sugar beet along with application the blending fertilizer at $100 \mathrm{~kg} \mathrm{~N} / \mathrm{fad}$ had the highest gross return 22103 and 23149 L.E./fad, followed by 21808 and 22785 L.E./fad as a result of application blending $\mathrm{N}$ fertilizer at $80 \mathrm{~kg} \mathrm{~N} / \mathrm{fad}$ in both seasons. On the other hand, the lowest values of gross return 18964 and 20057 L.E./fad were produced by intercropping two rows of onion with sugar beet that received $60 \mathrm{~kg} \mathrm{~N} / \mathrm{fad}$ in first and second season, respectively. Meanwhile, the maximum net return was 10840 and 11998 L.E./fad obtained by intercropping two rows of onion with sugar beet that received $80 \mathrm{~kg}$ $\mathrm{N} /$ fad. While increased onion plant density up to four rows with the lowest $\mathrm{N}$ fertilizer rate $60 \mathrm{~kg} \mathrm{~N} /$ fad were produced the lowest net return 7961 and 9007 L.E./fad in first and second season, respectively. That is indicated that the best onion plant density along with the optimum $\mathrm{N}$ fertilizer rate increased $\mathrm{N}$, which affected positively on productivity and net return. These results are in harmony with those obtained by Abdel-Wahab and El Manzlawy (2016) who reported 
that intercropping faba bean with four rows of wheat with the application of UF1 (238 kg N/ha) is more profitable to farmers than sole wheat that received the recommended mineral $\mathrm{N}$ fertilizer $(285.6 \mathrm{~kg} \mathrm{~N} / \mathrm{ha})$ for Egyptian farmers.

It is also evident that intercropping onion with sugar beet under any plant density or $\mathrm{N}$ fertilizer rate exceeded the solid sugar beet. The greatest benefit of intercropping was increasing grower profits (Abdel Motagally and Metwally, 2014; Masri and Safina, 2015; Zohry et al., 2017).

\section{CONCLUSION}

Data of this study indicated that intercropping two rows of onion with sugar beet and application blending $\mathrm{N}$ fertilizer (urea formaldehyde as slowrelease $\mathrm{N}$ fertilizer and traditional urea) at $80 \mathrm{~kg} / \mathrm{fad}$ had the highest sugar yield/fad, nitrogen use efficiency of both crops and net return as well as saved land area by 31 and 34\% comparative to the solid culture of sugar beet in both seasons, under sandy soil condition. Nematicide Vydate ${ }^{\circledR}$ (oxamyl) was the most effective treatment in reducing populations of root-knot nematode Meloidogyne spp. However, onion intercropped with sugar beet reduced numbers of rootknot nematode compared to sugar beet sole culture under field conditions.

\section{REFERENCES}

Abdel Motagally, F. A. and A. K. Metwally (2014). Maximizing productivity by intercropping onion on sugar beet. Asian Journal of Crop Science, 6(3): 226-235.

Abdel-Baset, Sahar. H. (2007). Pathological and biological studies on plant parasiticnematodes on Phaselous vulgaris. M.Sc. Thesis, Faculty of Agriculture, Suez Canal University, $115 \mathrm{pp}$.

Abdelkader, M. A. and A. A. M. Mohsen (2016). Effect of intercropping patterns on growth, yield components, chemical constituents and competition indices of onion, fennel and coriander plants. Zagazig Journal of Agricultural Research, 43(1): 67-83.

Abdel-Wahab, T. I. and A. M. El Manzlawy (2016). Yield and quality of intercropped wheat with faba bean under different wheat plant densities and slow-release nitrogen fertilizer rates in sandy soil. Journal of Experimental Agriculture International, 1-22.

Agu, C. M. (2008). Effects of intercropping on rootgall nematode disease on soybean (Glycine $\max (\mathrm{L}$.$) Merril). Plant Sciences Research,$ 1(1): 20-23.

Ahmed, A. G., N. M. Zaki and M. S. Hassanein (2007). Response of grain sorghum to different nitrogen sources. Research Journal of Agriculture and Biological Sciences, 3(6): 1002-1008.

Alam, M. M. (1992). Effect of ammonia on the population of plant parasitic nematodes and growth of some vegetables. Pakistan Journal of Nematology, 10: 133-137.

Bahr, A. A., M. S. Zeidan and M. Hozayn (2006). Yield and quality of maize (Zea mays L.) as affected by slow-release nitrogen in newly reclaimed sandy soil. American-Eurasian Journal of Agriculture and Environment Science, I(3): 239-242.

Besheit, S. Y., A. A. Abo Elwafa, A. A. Abo El-Hamd and M. A. Bekeet (2002). Quality and productivity of sugar beet as affected by intercropping onion in various densities. AlAzhar J. Agric. Res, 36: 87-101.

Barker, K. R. (1985). Nematode extraction and bioassays. Pp. 19-38, in: K. R. Barker, C. C. Carter and J. N. Sasser (eds.). An Advanced Treatise on Meloidogyne. Vol. II. Methodology. North Carolina State Univ. Graphics. Raleigh, N.C.

Black, C. A., D. D. Evans, I. I. White, L. E. Ensminger and F. E. Clark (1982). Methods of soil analysis. Amer. Soc. Agron. Inc., Ser. 9 in Agron., Madison, Wisconsin.

Bulletin of Statistical Cost Production and Net Return (2018). Winter Field Crops and Vegetables and Fruit, Agriculture Statistics and Economic Sector, Ministry of Egyptian Agriculture and Land Reclamation, Part (1), 2018.

Craswell, E. T. and D. C. Godwin (1984). The efficiency of nitrogen fertilizers applied to cereals in different climates. Advances in Plant Nutrition, 1:1-55.

Dandurand, L. M. and G. R. Knudsen (2016). Effect of the trap crop Solanum sisymbriifolium and two biocontrol fungi on reproduction of the potato cyst nematode, Globodera pallida. Annals of Applied Biology, 169(2): 180-189.

Daykin, M. E. and R. S. Hussey (1985). Staining and histo-pathological techniques in nematology. In: Barker K. R., C. C. Carter, J. N. Sasser, editors. An Advanced Treatise on Meloidogyne: Vol. II. Raleigh, NC: North Carolina State University Graphics; 39-48.

Dewit, C. T. (1960). On Competition. Verslag Landbou, Kundige Onderzoek, 66:1-28.

Dou, H. and A. K. Alva (1998). Nitrogen uptake and growth of two citrus rootstock seedlings in a sandy soil receiving different controlledrelease fertilizer sources. Biology and fertility of soils, 26(3): 169-172.

Draycott, A. P. (1993). Nutrition pp 239-278, In The Sugar Beet Crop: Science into practices. Edited by D.A. Cooke and R.K. Scott. Chapman \& Hall, 2-6 Boundary Row, London SEI 8HN. UK.

Drost, D. and R. Koenig (2002). Nitrogen use efficiency and onion yield increased with a polymer-coated nitrogen source. HortScience, 37(2): 338-342. 
Dunin, F. X., J. Williams, K. Verburg and B. A. Keating (1999). Can agricultural management emulate natural ecosystems in recharge control in southeastern Australia?. Agroforestry Systems, 45(1-3): 343-364.

El-Shamy, M., E. Moursi and M. EL-Mansoury (2015). Maximixing water productivity by intercropping onion with sugar beet in the north middle Nile delta region. Journal of Soil Sciences and Agricultural Engineering, 6(8): 961-982.

El-Shazly, M. A., R. A. El-Dissoky and M. S. Awaad (2014). Effect of soil amendments and nitrogen fertilizer sources on sugar beet productivity grown under salt affected soil conditions. Journal of Soil Sciences and Agricultural Engineering, 5(2): 267-278.

El-Shereif, A. C., A. R. Refaei, M. E. El-Nagar and H. M. Salem (2008). Influence of certain animal wastes urea and oxamyl on Meloidogyne incognita infecting eggplant. Egyptian Journal of Agronematology, 6: 99108.

Eskandari, H. (2012). Intercropping of maize (Zea mays L) with cowpea (Vigna sinensis) and mungbean (Vigna radiata): effect of complementarity of intercrop components on resource consumption, dry matter production and legumes forage quality. Journal of Basic and Applied Scientific Research, 2(1): 355360

Farghaly, B. S., A. A. Zohry and S. A. A. Bssaly (2003). Crop management for intercropping sugar beet with some essential crops to maximize area unit productivity. Journal ofAgricultural. Sciences. Mansoura Univ., 28: 5183-5199.

Freed, R. D. (1991). MSTATC Microcomputer Statistical Program. Michigan State University, East Lansing, Michigan.

Gohar, I. M. A. and M. F. Maareg (2005). Relationship between crop losses and initial population densities of root-knot nematode, Meloidogyne in soil of sugarbeet grown in West Nubariya district. Egyptian Journal of Agricultural Research, 83(4): 1315-1328.

Gohar, I. M. A., A. M. Abd El- Razek, A. A. Abo ElFtooh, M. M. Abd-El-Rahman and K. M. Agami (2012). The influence of some sugarbeet varieties and nematode, Ethoprop (MOCAP) on the root knot nematodefusarium disease complex at Ismailia and Nubaria regions. Minufiya Journal of Agriculture Research, 376(1): 1409-14270.

Gomez, K. A. and A. A. Gomez (1984). Statistical Procedures for Agricultural Re-search. $2^{\text {nd }}$ Edition, John Willey and Sons, Toronto.

Halbrendt, J. M. (1996). Allelopathy in the management of plant-parasitic nematodes. Journal of Nematology, 28(1): 8.

Haroutunian, G. (2013). The use of biofumigation crops as an alternative to Methyl Bromide for the management of the root-knot nematode in greenhouse cucumber production. Ph.D. Thesis. Paris Institute of Technology, $115 \mathrm{pp}$.

Hergert, G. W. (2010). Sugar beet fertilization. Sugar Tech., 12: 256-266.

Ibrahim, S. T., H. E. Khalil and A. S. Kamel (2005). Growth and productivity of sugar beet, onion and garlic grown alone and association under different inter and intraspacing. Annals of Agricultural Science, 43(2): 497-516.

Ismail, A. E. and M. M. Mohamed (2012). Nematicidal potentiality of some animal manures combined with urea against Meloidogyne arenaria and growth and productivity of sugar beet under field conditions. Pakistan Journal of Nematology, 30(1): 57-65.

Khan, M. M., M. Akhtar and K. Adbulkhliq (2001). Some competition functions and economics of different cotton-based intercropping systems. International Journal of Agriculture and Biology, 3(4): 428-431.

Li, T., H. Wang, X. Xia, S. Cao, J. Yao and L. Zhang (2018). Inhibitory effects of components from root exudates of Welsh onion against root knot nematodes. PloS One, 13(7): $\mathrm{e} 0201471$.

Masri, M. I. and S. A. Safina (2015). Agro-economic impact of intercropping canola and onion on some sugar beet varieties under different nitrogen rates. Journal of Plant Production, 6(10): 1661-1678.

Mead, R. and R. W. Willey (1980). The concept of a 'land equivalent ratio' and advantages in yields from intercropping. Experimental Agriculture, 16(3): 217-228.

Mojtahedi, H. and B. F. Lownsbery (1976). The effects of ammonia-generating fertilizer on Criconemoides xenoplax in pot cultures. Journal of nematology, 8(4): 306309.

Nicol, J. M., S. J. Turner, D. L. Coyne, L. Den Nijs, S. Hockland and Z. T. Maafi (2011). Current nematode threats to world agriculture. In Genomics and molecular genetics of plant-nematode interactions (pp. 21-43).

Norton, J. B. (2011). Nitrogen source, timing, and rate alternatives for furrow-irrigated sugarbeet. Crop Management, 10(1): 1-12.

Noweer, E. M. A. and A. A. S. Hassabo (2005). Effect of different management practices for controlling root-knot nematode Meloidogyne incognita on squach. Egyptian Journal of Phytopathology, 33(2): 73-81.

Oteifa, B. A. (1955). Nitrogen source of the host nutrition in relation to infection by a rootknot nematode, Meloidogyne incognita. Plant Disease Reporter, 39: 902-903.

Rodriguez-Kabana, R. (1986). Organic and inorganic nitrogen amendments to soil as nematode suppressants. Journal of Nematology, 18(2): 129.

Santana-Gomes, S. M., C. R. Dias-Arieira, M. Roldi, T. Santo Dadazio, P. M. Marini and D. A. de 
Oliveira Barizatilde (2013). Mineral nutrition in the control of nematodes. African Journal of Agricultural Research, 8(21): 2413-2420.

Shoji, S. and A. T. Gandez (1992). Controlled release fertilizer with polyolefin resin coating, development, properties and utilization. Konno Printing Co., Sendai, Japan, 63-75.

Sims, A. L. (2010). Challenging Current Nitrogen Recommendations: Sugar Beet Response to Nitrogen in Different RRV Locations and Soils-Report 1. Sugarbeet research and extension reports, 40: 87-98.

Taylor, A. L. and J. N. Sasser (1978). Biology, identification and control of root-knot nematodes (Meloidogyne species). Dept. Plant Pathol., North Carolina State Univ., U.S. Agency for Int. Dev. Raleigh, N.C. pp111.
Ueno, H. and S. Yamamuro (1996). Nitrogen dynamics and plant uptake in paddy field amended with slow release coat urea. Proceedings of the international symposium on maximizing sustainable rice yields through improved soil and environment management, 2: 857-865.

Zanón, M. J., L. A. Gutiérrez, A. Arbizzani and A. Myrta (2014). Control of tobacco nematodes with dimethyl disulfide (DMDS) in Spain and Italy. In VIII International Symposium on Chemical and Non-Chemical Soil and Substrate Disinfestation 1044 (pp. 375-380).

Zohry, A., K. Abbady, E. El-Mazz and H. Ahmed (2017). Maximizing land productivity by diversified cropping systems with different nitrogen fertilizer types. Acta Agriculturae Slovenica, 109(3): 481-492.

\section{تأثير تحميل البصل مع بنجر السكر على إنتاجية كلا المحصولين ومكافحة نيماتودا تعقد الجذور تحت

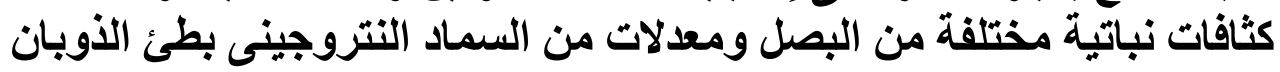

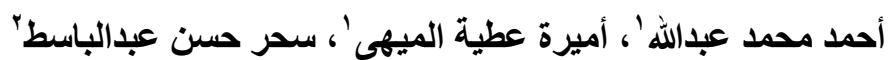

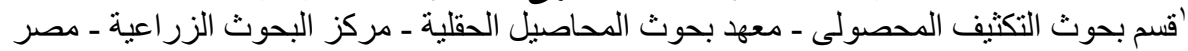

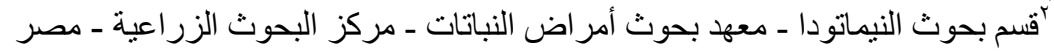

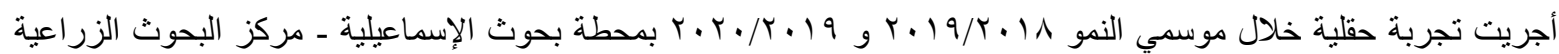

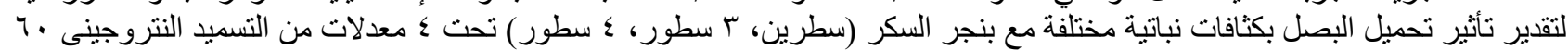

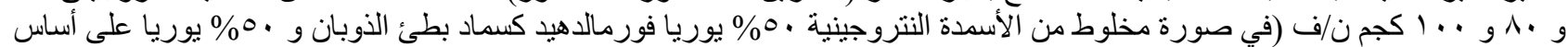

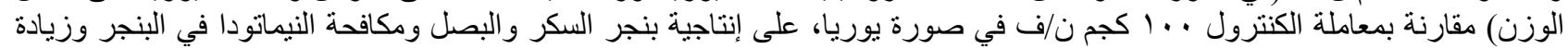

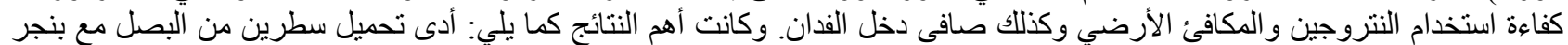

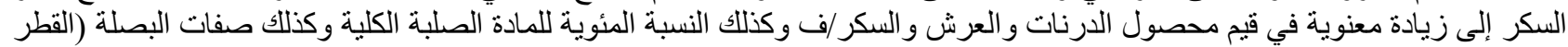

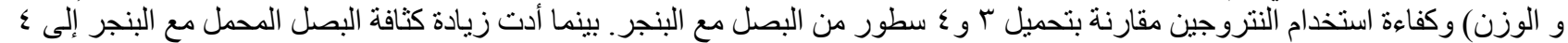

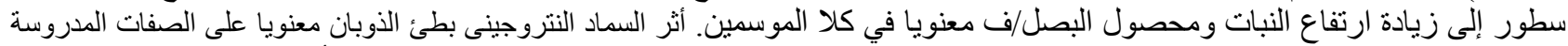

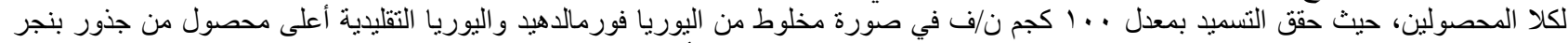

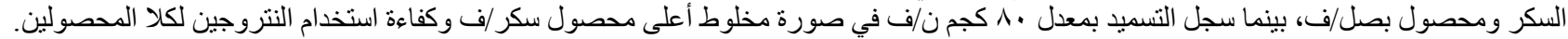

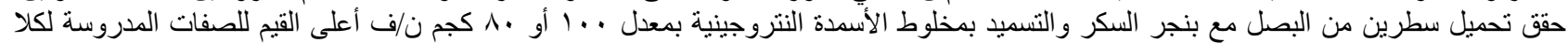

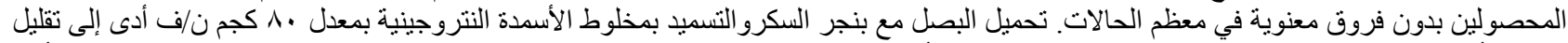

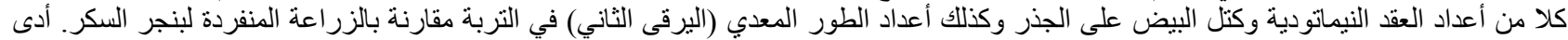

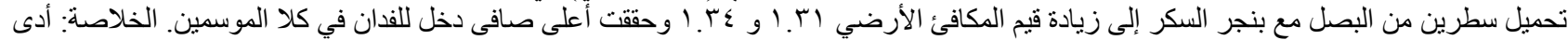

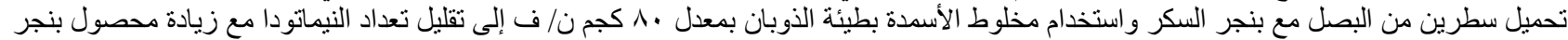
السكر، وحقق أعلى معدل لكفاءة استخدام الأرض وض و صافى دخل للمز ارع مع توفير استخدام الأسمدة النتروجينية. 